\title{
EFFECT OF BROILER DIET COMPOSITION ON NEWCASTLE DISEASE ANTIBODY PRODUCTION
}

\author{
A. M. Saeed Al Saigh \\ Dept. of Veterinary Puplic Health, College of Veterinary Medicine, Univ. of \\ Mosul, Iraq
}

\begin{abstract}
An experiment was conducted at the college of veterinary medicine to investigate the effect of two types of broiler starter diets, with or without animal protein, on Newcastle disease antibody production. Bursal weight index was also studied. Two replicates with 10 male broiler chicks, each were used in each treatment groups, A and B, for a total of 40 birds. The experimental birds were reared from day old till 4 weeks of age. Results revealed that there were no significant effects on antibody titer and bursal weight index, due to different types of the experimental diets. It was found that out of antibody titers 20 and 40 , only 3 and 2 birds were found to be positive, respectively. Where as out of antibody titers 80 and 160 only 3 birds from each group, A and B, where found to be positive verses 8 and 4 birds from group B were shown to be positive.
\end{abstract}

\section{INTRODUCTION}

There are extremely important interaction, synergism and antagonisms between nutrition and immunity that markedly affect productivity of poultry (Calnek et al,1997). Practically, there are many types of diets can be used for broilers. It is now more difficult to give general recommendations for allocation of these diets, since we now have the situation of broilers bird being processed at different ages .Therefor different nutrients are required according to the stages of production (Lesason and Summers,1997). Although there is a lack for many types from which the dietary level of nutrients required to supply adequate substrate to the immune system, to optimize disease resistance, is higher than the level set by the NRC (1994). However, for most requirement the levels that optimize growth and reproduction are also adequate for optimal immune competence(Pawison et al.,1996). Dietary manipulations of some nutrient result in immunoegulatory consequences due to the participation of the nutrient or it's products in communication within and between Leucocytes (Dietert et al.,1994). With the economy of many third world countries improving, there appears to be increased demand for animal products especially poultry meat is ideally suited to meet the increased demand for animal products with improved efficiency of production, and in this sense, chickens continue to be the least expensive meat in most countries. But, because feed still represents by far the major cost of production of all poultry products, there is continual need to evaluate new or different sources of ingredients and to continually re-examine the more common ingredients, especially if the effect of these feed ingredients on external environment is to be considered, in the manure nutrient residues. Currently the focus is on phosphorous and nitrogen 
excretion by animals, as expected becomes most critical in areas of very intensive production (Al-Zubeady, 1997). So nutritionist's role is to reduce manure nutrients residues, which revolves around diet formulation, the solution is the formulation of practical diets which provide a minimum excess of amino acids, by using methionine, lysine and threonine which are now available at competitive prices. However, it should be stressed that neither feed cost, nor effect of feed ingredients on the environment should overlooked the interactions between nutrition and immunity and infection diseases. Chiefly because, nutrition affects the immunocompetence, of birds and, thus their resistance to infectious diseases can be noticed. Partly because, immune response due do infections, challenges affect growth, reproduction, metabolism and nutrient requirements (Cary, 1985). So, the purpose of this study was to investigate the effect of feeding of two types of broiler diets, differed in their protein source on Newcastle disease antibody production.

\section{MATERIALS AND METHODS}

Fourty, day-old male broiler chicks (cobb) were individually weighted, wing banded and housed in heated battery brooders under continuos fluorescent lighting. Chicks were randomly divided into two groups (treatments), 20 chicks each, with two replicates of 10 chicks each, fed two types of diets (Table 1). Feed and water were given ad libitum.

level of $\mathrm{P}<0.05$ (Klasing, 1997).

Table (1): Diets used in experimental groups

\begin{tabular}{|l|c|c|}
\hline \multicolumn{1}{|c|}{ Inqrediant } & Group A\% & Group B\% \\
\hline Corn & 57.2 & 60.5 \\
\hline Soybean meal (48\%) & 31.5 & 30.7 \\
\hline Meat meal (50\%) & 1.0 & $\cdot$ \\
Fish meal (60\%) & 2.0 & - \\
\hline Fat (vegetable oil) & 4.6 & 4.5 \\
\hline Ground Limestone & 1.3 & 1.5 \\
\hline Calciun phosphate(20\%P) & 1.0 & 1.5 \\
\hline Iodized salt & 0.3 & 0.3 \\
\hline Vitamin: Mineral premix & 1.0 & 1.0 \\
\hline Methionine & 0.08 & 0.06 \\
\hline Crude protine \% & 21.8 & 20.0 \\
\hline Ether extract \% & 7.0 & 7.0 \\
\hline Metabolizable Energy(Kcal/kg) & 3045 & 3146 \\
\hline Calcium \% & 0.98 & 0.95 \\
\hline Available phosphorous\% & 0.42 & 0.42 \\
\hline Sodium \% & 0.18 & 0.17 \\
\hline Methionine & 0.46 & 0.40 \\
\hline Lysin \% & 1.27 & 1.10 \\
\hline Methionine \& cystine & 0.80 & 0.71 \\
\hline Tryptophane & 0.30 & 0.28 \\
\hline
\end{tabular}




\begin{tabular}{|c|c|c|}
\hline Threonine\% & 0.94 & 0.86 \\
\hline Newcastle disease (ND) La sota vaccine (TAD), with $10^{6}$ EID 50/ml
\end{tabular}
was used in the drinking water for the purpose of vaccination as recommended by Sibbald (1987). All groups were vaccinated at 7 and 21 days of age. Individual blood samples were collected from the experimental birds at 28 days of age by cardiac puncture, for the measurement of haemagglutination inhibition (H1) test. After that, birds were killed by cervical dislocation, bursa of Fabricious were taken for determination of bursal weight index using the following equation:

Bursal weight index $=$ bursal weight/body weight $* 1000$. ]

Statistical analysis was performed using student's -t- test with significant

\section{RESULTS AND DISCUSSION}

Antibody titer: Hemagglutination inhibition titers of both broiler groups A and $\mathrm{B}$ is presented in figure 1 .

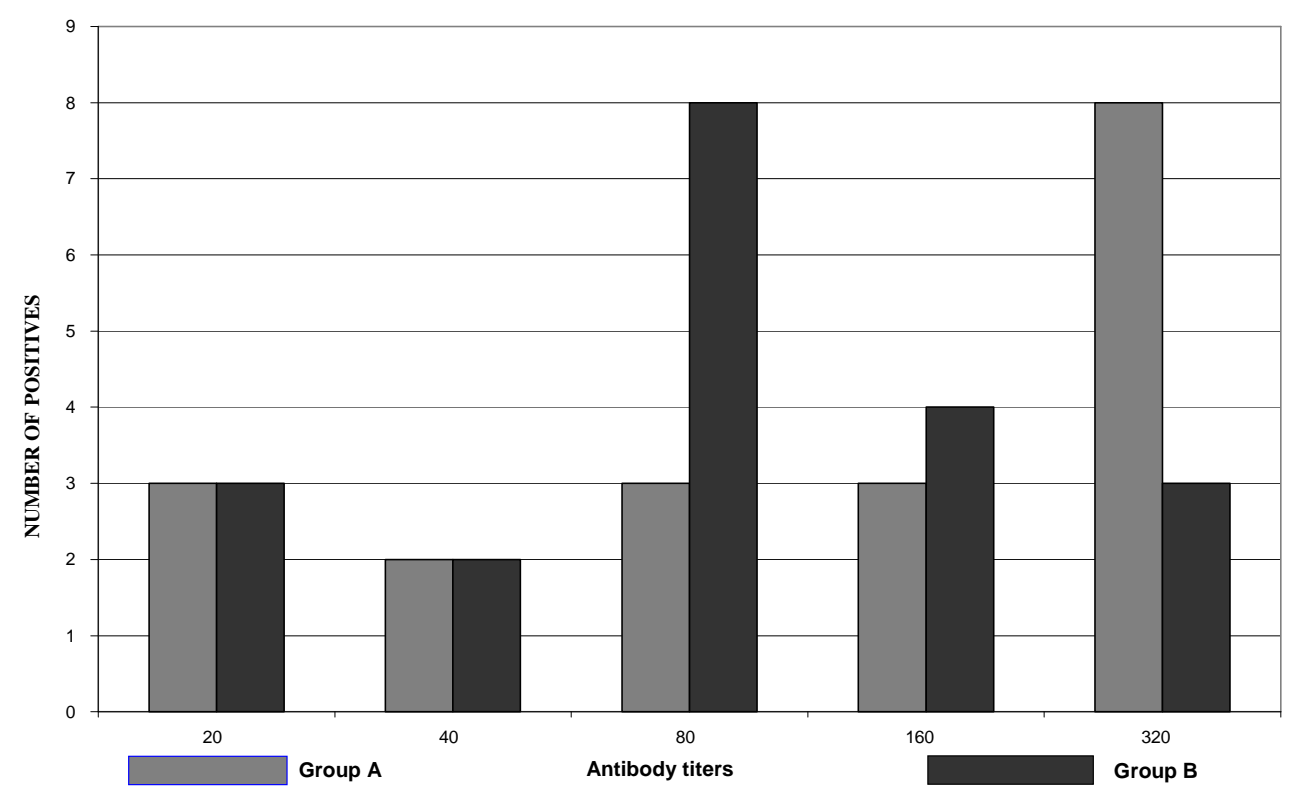

Figure (1): Hemagglutination inhibition titers of birds in two broiler at age 28 days. groups

From figure 1 , it is evident that same number of chicks in both treatments groups (A and B) showed positive antibody titers 20(3 chicks), and for titer 40, (2chicks), respectively. In titers 80 and 160, more numbers of birds in group B were shown to be positive with these titers than chicks in group A, which were 8 and 4 chicks in group B. While they were 3 chicks in both titers in group A. On the other hand, At titer 320,only 8 birds in group A showed positive response, while only 3 chicks in group $B$ were found to be positive.

From figure 2, it is clear that chicks in group A had higher geometric mean (1.098) than those of group B (0.909).

Bursal weight index: Bursal weight index of each bird in each of both groups, are shown in figure (3). 
It is evident that bursal weight index of birds in both groups (A and B) were occur within the normal range of 2-4. However, statistically no Differences were noticed in bursal weight index between both groups of chicks.

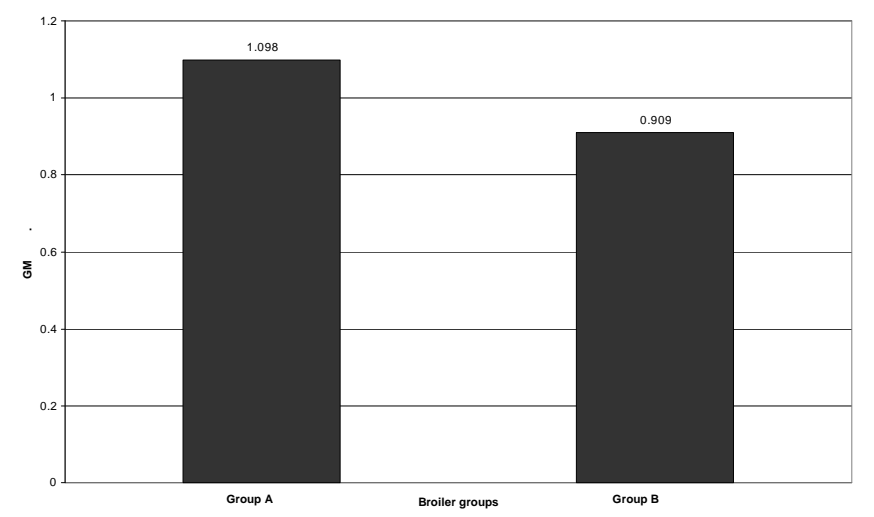

Figure (2): Geometric mean of Newcastle antibody titer of two broiler chicks at 28 days of age.

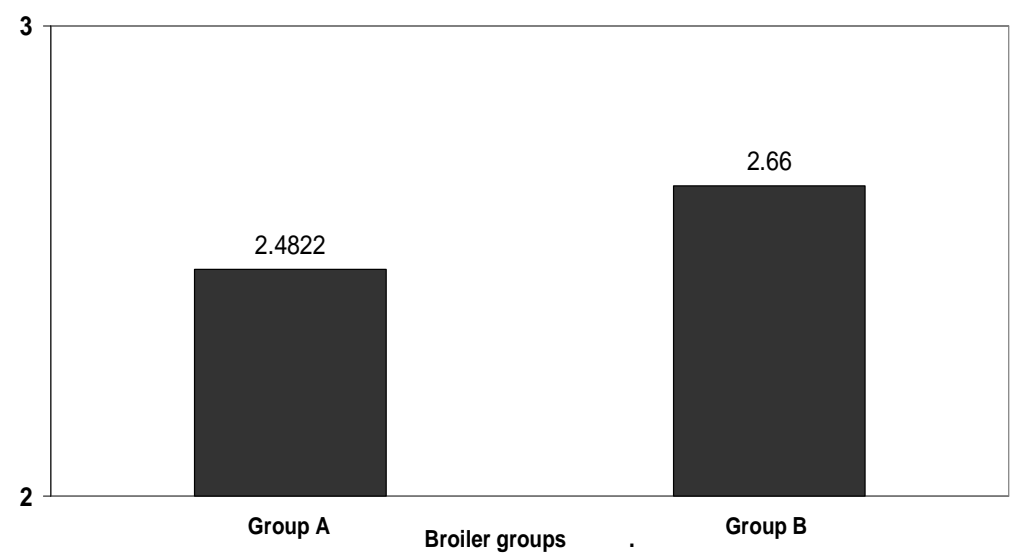

Figure 3: bursal weight index of chicks in both broiler groups.

In this experiment, it was tried to elucidate if there is an effect of formulating broiler diets of tow different types (with or without animal protein), on the immune response of broilers to vaccination with NDV vaccine. It was found that there is no significant differences in the geometric mean in HI titers in both groups of chicks which is a reflect of antibody titers experienced by chicks in both groups of chicks.

Moreover, feeding both types of feed had also no significant effect on the relative bursal weight of these chicks. As it is well known that attention with regard to NDV vaccination must be focused more on the possible factors affecting the immunological response of the birds to vaccination and not to the vaccine alone, but at the same time, however, feed must not be over looked. The result showed that, attaining the required protein and metabolizable energy levels, feed with or without animal protein could be used with out adverse effect on NDV, antibody response, or any index of immunity like bursal weight index. 


\section{الخلاصة}

تم تنفيذ تجربة في كلية الطب البيطري لدراسة تأثثير نوع البادئ (بإضافة أو عدم إضافة إنافة

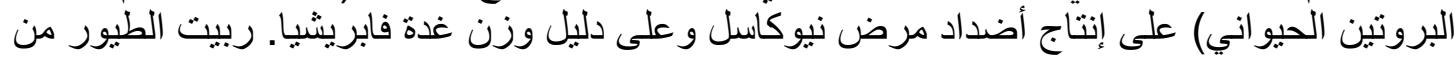

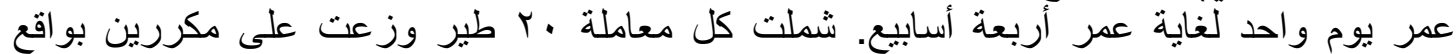

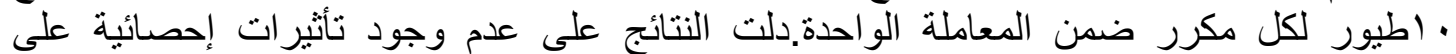

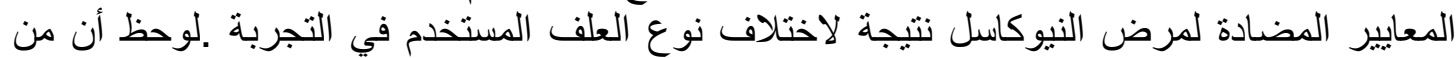

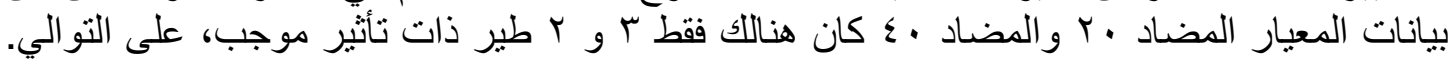

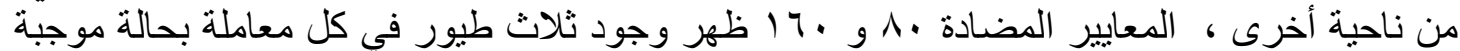

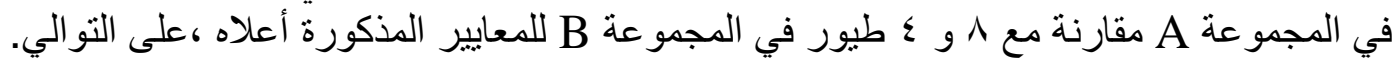

\section{REFERENCES}

Al-Zubeady, AZD (1997). Detection of maternally derived antibodies against chicken Newcastle disease virus in eggs and chicks, and its correlation with the degree of protection and challenge. M.Sc.thesis, Mosul University: 1-86.

Calnek, B.W., HJ, Bareanes CW, MC Beard LR,Dougald Y,Saif (1997). Diseases of poultry. $10^{\text {th }}$ Edition Mosby-wolfe. USA.

Cary, N.C. (1985).SAS Institute. Statistic. SAS users guide. Version 5 edition. SAS institute.

Dietert, R. R., K. A.,Golemboski, R.E Austic,.(1994).Environment-immune interactions . Poult Sci, 73: 1062-1076.

Klasing, K.C. (1997).Interactions between nutrition and infectious disease. In Calnek W., Barnes HT, Beard CW, MC Dougald LR, Saif YM. diseases of poultry $10^{\text {th }} \mathrm{ed}$. Mosby-wolfe.USA.

Lesason, S. J. D.Summers, (1997). Commercial Poultry Nutrition, 2nd edition. University Books. Guelph.

National academy of sciences (1994). Nutrient requirements poultry. 9th Rev. Ed. NAS Washington, D.C.

Pawison, T. F., T. R, Morris, L.N. Payne (1996).Poultry Immunology. Published by car fax Publishing Company, England.

Sibbald, I. R. (1987). Examination of bioavailable amino acids in feed stuffs poultry and pigs: a review with emphasis on badance experiments. Can J. Anim. Sci: 67: 221-301. 